ДАРЧИЕВА Светлана Валерьевна - кандидат исторических наук, доцент; старший научный сотрудник Северо-Осетинского института гуманитарных и социальных исследований им. В.И. Абаева - филиала Владикавказского научного иентра РАН (362035, Россия, Республика Северная Осетия, г. Владикавказ, ул. Галковского, 200; svetik-dar70@таil.ru)

\title{
ГОСУДАРСТВЕННАЯ ДУМА И ФОРМИРОВАНИЕ НОВЫХ НАЦИОНАЛЬНЫХ ПОЛИТИЧЕСКИХ ЭЛИТ НА СЕВЕРНОМ КАВКАЗЕ (1906-1917 гг.)
}

\begin{abstract}
Аннотация. Целью настоящего исследования является определение роли первого российского парламента в формировании новой политической элиты Северного Кавказа. В статье анализируется деятельность северокавказских депутатов в решении наиболее актуальных вопросов социально-экономической жизни региона. Научная новизна исследования заключается в рассмотрении Государственной думы как важнейшего фактора развития политической культуры народов России. После Февральской революции 1917 г. северокавказские депутаты Государственной думы различных созывов участвовали как во Временном правительстве, так и в национальных и региональных правительствах, составив весомое кадровое ядро национальных политических элит в новых независимых государствах, которые появились после распада Российской империи.
\end{abstract}

Ключевые слова: Государственная дума Российской империи, северокавказские депутаты, Терская область, национальные элиты

$\Pi$ оследовавшая за присоединением Северного Кавказа его интеграция в систему управления Российской империи изначально не ограничивалась только лишь административно-политическими мерами. Одним из успешных и апробированных методов имперских властей стало вовлечение северокавказских народов в общероссийское политико-правовое пространство, что способствовало укреплению российской власти в регионе и формированию имперской идентичности и сознания.

Реформы политической системы Российской империи 1905-1906 гг., подготовленные и осуществленные передовой частью российской элиты, по сути, открывали для государства и общества путь конституционного развития. Новые веяния не могли не затронуть и национальные регионы России. Здесь деятельность поборников социально-политических и культурных преобразований во многом координировалась национально-региональными фракциями российского парламента.

В состав созданного в 1906 г. российского парламента вошли выборные представители национальных регионов России. Порядок выбора северокавказских депутатов был определен высочайшим указом императора Николая II ${ }^{1}$. Согласно данному указу, депутатов избирали специальные собрания выборщиков, в которых пропорциональное соотношение представителей различных социальных групп было установлено с явным предпочтением к казакам и землевладельцам ${ }^{2}$. За все время существования Думы всех четырех созывов в ее состав входили 25 депутатов от Северного Кавказа. В I Государственной думе Кубанскую область представляли кадеты К.Л. Бардиж, А.А. Гришай, Н.Г. Кочевский, трудовики М.И. Свешников, В.И. Лунин, Н.И. Морев и бес-

1 Центральный государственный архив Республики Северная Осетия - Алания (ЦГА РСО-А). Ф. 216. Оп. 1. Д. 2. 1906. Л. 9.

2 Избирательный закон в Государственную Думу по Кавказу. 3 июня 1907 г. Баку: А.А. Дамми. 1912. С. 15. 
партийный В.К. Константинов. Терскую область представляли беспартийный П.П. Димиров, трудовик А.П. Маслов и член мусульманской группы Т.Э. Эльдарханов.

Во II Государственной думе Кубанскую область и Черноморскую губернию представляли П.Г. Кудрявцев (примкнул к кадетам, затем вошел в казачью группу), Л.Ф. Герус (примкнул к социал-демократической партии), В.И. Митров (примкнул к социал-демократической партии), Ф.А. Щербина (вошел в казачью группу), П.С. Ширский (социалист-революционер). Терскую область представляли Г.А. Горбунов (социалист-революционер), М.А. Караулов - депутат II и IV Думы (вошел в казачью группу). Члены мусульманской группы А.А. Кардашов и Б. Султанов представляли Дагестанскую область и Закатальский округ.

В III Государственной думе октябристы Е.И. Тихонов и Н.В. Лисичкин вместе с социал-демократом Покровским представляли Терскую и Кубанскую области и Черноморскую губернию. Социал-демократ И.И. Гайдаров, примкнувший впоследствии к мусульманской группе, представлял Дагестанскую область и Закатальский округ.

B IV Государственной думе кадет Н.Н. Николаев представлял Терскую и Кубанскую области и Черноморскую губернию, а Дагестанскую область и Закатальский округ - прогрессист М.М. Далгат ${ }^{1}$.

Анализ партийного состава северокавказских депутатов Государственной думы показывает, что кадеты, как правило, избирались от Кубанской области, социал-демократы - от Дагестанской и Терской областей, а Ставропольскую губернию чаще всего представляли трудовики. Принимая активное участие в парламентских обсуждениях наиболее животрепещущих проблем российского общества, депутаты от Северного Кавказа на первое место выдвигали аграрный вопрос, решение которого они связывали с обеспечением гражданских свобод и установлением демократического самоуправления в регионах ${ }^{2}$.

Другим важнейшим направлением деятельности северокавказских депутатов был национальный вопрос, обсуждение которого они неоднократно инициировали. Решение данного вопроса депутаты видели в установлении национального равноправия, обеспечении права наций на самоопределение и в создании необходимых условий для развития национальных культур. По мнению депутатов Т.Э. Эльдарханова, А.П. Маслова, Г.А. Горбунова, П.П. Димитрова, М.А. Караулова, К.Л. Бардижа, для решения национального вопроса требовались также меры административного и экономического характера, а именно введение самоуправления, распространение законов, действующих в центре, на национальные окраины, расширение экономических прав национальной буржуазии. Все политические партии Государственной думы России в своих программных документах придавали большое значение национальному вопросу. В то же время далеко не все они решались признать принцип самоопределения наций. Либеральные, социалистические, монархические партии понимали его по-разному. Если в вопросах культурного развития народов России либералы и социалисты проявляли относительное единодушие, то в понимании того, какое место они должны занимать в будущем государственном устройстве, между ними возникали серьезные разногласия. Идеалом для либерально настроенных депутатов являлось не этническое, а гражданское государство, в то время как социалисты оставались сторонниками национального госу-

\footnotetext{
1 Депутаты от Северного Кавказа в Государственной думе Российской империи (19061917 г2.): энциклопедический справочник. 2009. Владикавказ. Сев.-Осет. ин-т гум. и соц. исслед. им. В.И. Абаева. С. 5.
} 
дарства, считая его объективной исторической и общемировой тенденцией. Именно поэтому уже в программе РСДРП присутствовала идея политического самоопределения, создававшая идеологическую основу для создания самостоятельных национальных государств, и позднее, в 1913 г., большевики открыто отстаивали этот принцип [Карапетян 2001: 194]. В противовес социалистам либералы видели в признании права наций на самоопределение определенную угрозу самой российской государственности и, соответственно, категорически выступали против реформирования государственной организации на федеративных принципах.

Многие известные представители национальных элит, став депутатами Думы, сформировались как политические деятели. Следует отметить, что само звание депутата Государственной думы наделяло его носителя особым авторитетом в национальных регионах. Одним из видных представителей горской интеллигенции был депутат Т.Э. Эльдарханов, представлявший в I и II Государственной думе горское население Терской области. Работая учителем грозненской школы, он внес ощутимый вклад в культурно-просветительную деятельность местной интеллигенции. Эльдарханов подготовил на основе русской графики «Чеченский букварь» и издал его в 1911 г. в Тифлисе. Он преподавал русский язык и боролся за увеличение числа школ в области ${ }^{1}$ [Darchieva, Darchiev 2019].

Т.Э. Эльдарханов придерживался кадетских взглядов и выступал в поддержку кадетских законопроектов о гражданском равенстве и по аграрному вопросу (так называемый проект 42-х). Эльдарханов был сторонником мирной интеграции чеченцев в общероссийскую государственно-правовую и культурную среду, но при условии сохранения национальной самобытности и, главное, добрососедских отношений с другими горскими народами. Свои принципы и убеждения Эльдарханов воплощал в конкретные действия. В 1906 г. для охраны помещичьих усадеб начали привлекать чеченцев, следствием чего стали жестокие столкновения горцев с местным населением. Эльдарханов решительно выступил против такой порочной практики и инициировал запрос, в котором депутаты обращались к правительству со следующим вопросом: «Намерен ли председатель Совета министров принять меры к немедленному возвращению стражников-горцев и к прекращению преступной агитации правительственных агентов для набора новых?»2 Депутаты от различных национальных групп, как правило, заявляли об отсутствии сепаратистских проявлений в своих регионах и об их полной лояльности имперскому правительству. Эльдарханов также стремился доказать отсутствие на Кавказе сепаратизма как явления, а в возникающих иногда эксцессах видел следствие избыточных карательных мер центральной власти ${ }^{3}$.

В работе II Государственной думы Эльдарханов подписал кадетский вариант Проекта основных положений об отмене ограничений в политических и гражданских правах, связанных с вероисповеданием и национальностью (18.05.1907). Именно поэтому Эльдарханов был впоследствии отстранен от выборов в III Думу. С октября 1917 г. по 1920 г. Эльдарханов возглавлял Грозненский окружной исполнительный комитет. В 1921 г. Эльдарханов был включен в состав горской делегации, направленной в Народный комиссариат по делам национальностей РСФСР для участия в работе над проектом

1 Мусульманские депутаты Государственной думы России, 1906-1917 г2.: сборник документов и материалов (сост. Л.Я. Якмаева). Уфа: Китап. 1998. С. 312-313.

2 Государственная дума. Первый созыв: стенографические отчеты. 1906. СПб. Сессия 1. Стб. 1694.

3 Там же. Стб. 1227. 
Конституции Горской автономной социалистической советской республики. В апреле 1921 г. Учредительный съезд Горской АССР избрал Эльдарханова председателем президиума ЦИКа, а в 1922 г. он стал заместителем наркома просвещения Горской АССР. В 1923 г. он был назначен председателем Чеченского областного ревкома [Сайдумов 2020: 74].

Одним из наиболее видных деятелей общественно-политической мысли Дагестана начала XX в. был депутат III Думы (1907-1912 гг.) И.И. Гайдаров. В 1907 г. он окончил Петербургский институт инженеров путей сообщения. И.И. Гайдаров приобрел большую популярность в период деятельности в III Государственной думе. Его выступления отличались особой остротой, полемичностью и принципиальностью. Он резко критиковал политику правительства в отношении нехристианских вероисповеданий, характеризуя ее как дискриминационную. По завершении срока депутатских полномочий Гайдаров вернулся в Дагестан. Позднее, в 1912 г., он принял участие в выборах в IV Думу, но, к сожалению, в этот раз безуспешно. Тем не менее Гайдаров продолжал вести активную общественную и политическую деятельность: в том же 1912 г. его избрали депутатом Бакинской городской управы, а уже через 6 лет он стал министром транспорта, почты и телеграфа Горского правительства. 28 мая 1918 г. была провозглашена Азербайджанская демократическая республика, в которой Гайдаров непродолжительное время (с мая по июнь 1918 г.) являлся министром государственного контроля. В конце 1920 г. Ибрагим-бек отправился в меньшевистскую Грузию. С установлением на Кавказе советской власти Гайдаров вместе с семьей переехал во Францию, став одним из лидеров кавказской эмиграции. В 1922 г. в Париже была образована масонская ложа «Астрея», в которую вошли крупные российские деятели. В ходе формирования и деятельности данной ложи руководители ее обратили внимание на представителей Кавказа, которые так же, как и русские, оказались в эмиграции. Оказавшись во Франции, Гайдаров вступил в масонскую ложу 15.12.1923 г., где получил 1-й градус (ученик) [Бабич 2014: 101-102].

С 1925 г. Ибрагим-бек живет в Турции. Он скончался в 1949 г., будучи членом Высшего научного совета Министерства благоустройства в г. Анкаре. Похоронен на кладбище «Джебечи» в Анкаре [Абдуллаев 1987: 99].

Значительную роль в деятельности IV Думы сыграл М.M. Далгат, известный общественный деятель, врач и политик. Будучи редактором газеты «Голос Кавказа», Далгат стремился поднимать на страницах издания наиболее важные для всего Кавказа социально-политические проблемы. В своих статьях Далгат не боялся выступать против той политики, которую царское правительство проводило в отношении крестьян на Северном Кавказе. Став депутатом, М.М. Далгат и с думской трибуны продолжал отстаивать интересы горских народов, хотя большая часть внесенных им на рассмотрение законопроектов была отклонена правой Думой. Критические выступления Далгата в адрес царской администрации на Кавказе были столь острыми и бескомпромиссными, что вносимые им законопроекты не решались поддержать даже социалдемократы и трудовики [Абдуллаев 1995: 76]. После Февральской революции 1917 г. Далгат был направлен Временным правительством на Северный Кавказ для содействия в создании на местах новых продовольственных комитетов. С марта по апрель 1917 г. он являлся комиссаром Временного комитета Временного правительства в Дагестанской области и Закатальском округе. После Октября 1917 г. признал советскую власть и до конца жизни работал врачом в г. Владикавказе.

Большим авторитетом пользовались казачьи политические деятели Думы. К.Л. Бардиж, А.Ф. Щербина и М.А. Караулов, представлявшие либерально- 
демократическое течение казачьей интеллигенции, не рассматривали казачество как противовес горским народам, удерживающий их в повиновении царской власти. Они были сторонниками крепких добрососедских отношений всех народов Терской области. Непременным фактором гармоничного развития края казачьи депутаты считали введение местного самоуправления.

Офицер Кубанского казачьего войска К.Л. Бардиж был депутатом Думы всех четырех созывов. Примыкая по своим убеждениям к конституционным демократам, Бардиж поддержал ряд заявлений, в т.ч. «Об избрании комиссии о неприкосновенности личности», «Об увеличении числа членов комитета по государственной обороне 5-ю членами» и др. В период с 1914 по 1918 г. он являлся председателем Екатеринодарского комитета Всероссийского земского союза помощи больным и раненым воинам. После Февральской революции 1917 г. Бардиж был назначен комиссаром Временного комитета Государственной думы и Временного правительства на Кубани. Во время корниловского выступления Бардиж призвал население «сохранять полное спокойствие и порядок и воздерживаться от каких бы то ни было активных выступлений, могущих повлечь братоубийственную гражданскую войну» [Памяти погибших 1929: 54-57]. В ноябре 1917 г. он вошел в состав правительства Юго-восточного союза казачьих войск, горцев Кавказа и вольных народов степей. Будучи ярым противником советской власти, Бардиж активно участвовал в организации вооруженной борьбы с ней. В конце февраля 1918 г. недалеко от Туапсе, в станице Воронцовке К.Л. Бардиж был схвачен красноармейцами и 9 марта расстрелян. Депутат II Думы от Кубанской области и Черноморской губернии Ф.А. Щербина был крупным ученым. Он окончил Петровскую земледельческую академию и профессионально занимался исследованием крестьянского вопроса. Щербина стоял на позициях Народно-социалистической партии и входил в казачью группу (был ее председателем). Основным направлением его депутатской деятельности стало решение аграрного вопроса в России. Щербина поддержал Февральскую революцию 1917 г., но, как сторонник эволюционного развития общества, он крайне отрицательно отнесся к октябрьским событиям 1917 г., которые, по его мнению, принесли населению России «физическое разрушение и нравственное растление». В марте 1918 г. Щербина вместе с Добровольческой армией покидает Екатеринодар, но уже в августе возвращается с частями Деникинской армии. До 1920 г. он являлся постоянным членом Кубанской краевой рады, руководителем ряда комиссий (статистической, финансово-бюджетной) и Статистического комитета при Кубанском краевом правительстве, профессором статистики Кубанского политехнического института, Северо-Кавказского политехникума и кооперативных курсов в Екатеринодаре ${ }^{1}$.

В 1920 г. он эмигрировал в Югославию, а затем обосновался в Праге. За границей Щербина продолжает активную политическую и педагогическую деятельность, став духовным лидером казаков-эмигрантов. Он основал Общество изучения казачества, а также возглавил Общество кубанцев в Чехословакии. Венцом его педагогической деятельности в эмиграции стало преподавание в Украинском вольном университете (1922-1936) и работа профессором статистики Украинской государственной академии в г. Падебрады ${ }^{2}$.

Итак, Государственная дума Российской империи явилась политиче-

1 Депутаты от Северного Кавказа в Государственной думе Российской империи (19061917 г2.): энциклопедический справочник. 2009. Владикавказ. Сев.-Осет. ин-т гум. и соц. исслед. им. В.И. Абаева. С. 121-123.

2 Государственная дума Российской империи: энциклопедия. В 2 т. Т. 1. 1906-1917 (отв. ред. В.В. Шелохаев). М.: РОССПЭН. 2006. С. 742-743. 
ской школой и фактором складывания новых национальных элит. Депутаты Государственной думы являлись составной частью правящей элиты России. За время работы Думы (1906-1917 гг.) депутатский корпус подвергся эволюции, приведшей к тому, что только меньшая часть состава Думы продолжала работать в рамках думского парламентаризма. К февралю 1917 г. только Дума оставалась единственным легитимным органом народного представительства и источником власти. После Февральской революции 1917 г. создается Временный комитет Государственной думы, комиссары которого бесперебойно обеспечивали работу государственного аппарата, способствовали проведению демократических реформ в управлении страной и активно участвовали в политической жизни своих регионов. Северокавказские депутаты Государственной думы различных созывов участвовали в работе как Временного правительства, так и национальных и региональных правительств, составили весомое кадровое ядро национальных политических элит, закрепившихся в новых независимых государствах, которые появились после распада Российской империи.

\section{Список литературы}

Абдуллаев М.А. 1987. Общественно-политическая мысль в Дагестане в начале ХХ в. М.: Наука. 324 с.

Абдуллаев М.А. 1995. Из культурно-философского наследия Дагестана. Ч. 2. Махачкала: Юпитер. 188 с.

Бабич И.Л. 2014. Кавказцы в русских масонских ложах Франции (19221939 гг.). - Кавказ \& Глобализация. Т. 8. Вып. 3-4. С. 98-116.

Карапетян Л.А. 2001. У истоков российской многопартийности: СевероКавказский регион (конеи, 90-х гг. ХІХ в. - февраль 1917 г.). Краснодар: Краснодарский государственный университет культуры и искусств. 375 с.

Памяти погибших (под ред. Н.И. Астрова, П.Н. Милюкова и др.). 1929. Париж. 240 с.

Сайдумов М.X. 2020. Таштемир Эльдарханов: чеченский государственник царского и советского периода истории. - Вестник КНИИ РАН. № 2(2). C. 71-76.

Darchieva S.V., Darchiev A.V. 2019. Issues of Education and National Culture in the Work of North Caucasian Deputies of the State Duma of the Russian Empire (1907-1912). - European Journal of Contemporary Education. Vol. 8. No. 3. P. 638645.

DARCHIEVA Svetlana Valerievna, Cand.Sci. (Hist.), Associate Professor; Senior Researcher of the North Ossetian Institute for Humanitarian and Social Studies - Branch of the Vladikavkaz Scientific Center, Russian Academy of Sciences (200 Galkovskogo St, Vladikavkaz, North Ossetia - Alania, Russia, 362035; svetik-dar70@mail.ru)

\section{THE STATE DUMA AND THE FORMATION OF NEW NATIONAL POLITICAL ELITES IN THE NORTH CAUCASUS (1906-1917)}

\footnotetext{
Abstract. The aim of this research is to define the role of the very first Russian parliament in the formation of new political elite in the North Caucasus. The manifesto of October 17, 1905 along with guarantees of civil rights and freedoms, gave impetus to the creation of regional public and political organizations, the establishment and strengthening of national selfawareness and the national political elite of the peoples of Russia. The North Caucasus was no exception. Under the slogan of constitutional dialogue with the authorities, the local political elite sought to develop their own line of behavior.
} 
The article analyzes the activities of North Caucasian deputies in terms of solving the most pressing issues of social and economic life in the region. The scientific novelty of the research consists in considering the State Duma as the most important factor in the development of the political culture of the peoples of Russia.

The author concludes that the Duma presented new political opportunities to representatives of regions and peoples of the Empire. First of all, they could now get elected legally and legitimately for ethnic and regional representation in Russia's first Parliament; secondly, they got to represent their national interests from the Duma rostrum; and thirdly, it allowed them to establish ethnic and regional political organizations.

Keywords: State Duma of Russian Empire, North Caucasus deputies, Terek region, national elites

ДЗЮБАН Валерий Валерьевич - доктор исторических наук, кандидат педагогических наук; профессор департамента социологии, истории и философии Финансового университета при Правительстве РФ (125993, Россия, г. Москва, Ленинградский пр-кт, 49; bryanskstudzuban@mail.ru)

\title{
ДЕЯТЕЛЬНОСТЬ СОВЕТСКОЙ ВНЕШНЕЙ ВОЕННОЙ РАЗВЕДКИ В ГОДЫ ВЕЛИКОЙ ОТЕЧЕСТВЕННОЙ ВОЙНЫ 1941-1945 гr.
}

\begin{abstract}
Аннотация. Статья посвящена деятельности советской внешней военной разведки в годы Великой Отечественной войны. Автор рассматривает подвиги разведчиков в борьбе с нацистской Германией и подконтрольными ей странами, анализирует структуру разведывательных органов, работавших в тылу врага, определяет поставленные перед разведкой задачи и итоги их выполнения, оценивает вклад в победу в войне и значение разведывательных операций в общей картине событий.

Данная тема является актуальной в наши дни, когда раскрываются секретные архивы, и их содержание становится достоянием общественности, люди узнают все больше имен героев Великой Отечественной войны. Очень важно сохранить память об их подвигах в памяти российской молодежи, таким образом воспитывая в них уважение к истории нашей страны.
\end{abstract}

Ключевые слова: внешняя разведка, разведчик, тыл, контрразведка, агент, подвиг

C каждым днем от нас все сильнее отдаляется время войны, с каждым годом становится все меньше очевидцев тех событий, которые могли бы поведать о том, что было в действительности. До сих пор остаются неизвестными некоторые операции спецслужб и вклад, который они внесли в достижение Великой Победы, не оценены должным образом подвиги разведчиков, работавших в тылу врага, настоящее значение переданных ими данных, оказавших исключительно важное влияние на итоги Великой Отечественной войны.

«В настоящее время под разведкой понимается практика и теория сбора информации о противнике или конкуренте для безопасности и получения преимуществ в области вооруженных сил, политики или экономики. Это, как правило, хорошо организованные действия на правительственном или корпоративном уровне» [Рашевский 2010: 4].

В первые годы войны вопросами государственной безопасности Советского Союза занимался Народный комиссариат госбезопасности и органы военной контрразведки. Деятельность разведывательных организаций начала активизироваться в 1940 г., когда стало очевидным, что Германия готовится к нападению на Советский Союз. Подтверждением тому служили сообщения из Токио и Берна, а немного позже - и из Берлина, Вашингтона, Лондона, Анкары, 